Преображенский А. Этимологический словарь русского языка : в 2 т. М., 1910-1914.

Фасмер М. Этимологический словарь русского языка : в 4 т. / пер. с нем. и доп. О. Н. Трубачева. М., 1986-1987.

Шанский - Этимологический словарь русского языка / под ред. и рук. Н. М. Шанского. М., 1963-. Т. 1-.

ЭССЯ - Этимологический словарь славянских языков: Праславянский лексический фонд / под ред. О. Н. Трубачева (вып. 1-32), А. Ф. Журавлева (вып. 33-39), Ж. Ж. Варбот (вып. 40-). М., 1974-. Вып. 1-.

Berneker E. Slavisches etymologisches Wörterbuch. Bd. 1-2. Heidelberg, 1908-1913.

Bezlaj F. Etimološki slovar slovenskega jezika. Knj. 1-5. Ljubljana, 1977-2007.

Matzenauer $A$. Př́íspěvky ke slovanskému jazykozpytu // Listy filologické a paedagogické. 1881. № 8. S. 161-190.

Miklosich Fr. Etymologisches Wörterbuch der slavischen Sprachen. Wien, 1886.

Skok P. Etimologijski rječnik hrvatskoga ili srpskoga jezika. Knj. 1-4. Zagreb, 1971-1974.

DOI $10.31168 / 7996-2700-3.10$

\author{
О. В. Белова \\ Институт славяноведения РАН \\ Москва, Россия \\ kotmonya@yandex.ru
}

\title{
Смоленские «авдотки» в контексте городского текста и традиционной обрядности
}

C середины XIX в. в краеведческой и этнографической литературе, посвященной Смоленску, спорадически встречается упоминание о паломничестве, ежегодно совершавшемся белорусскими крестьянами и крестьянками окрестных уездов на праздник Вознесения Господня в Вознесенский женский монастырь. Целью паломниц было, помимо прочего, посещение на монастырском кладбище могилы, надгробие которой было украшено изображением амуров, получивших в местной устной традиции название каменные деточки (с ними связаны городские легенды о проклятых или безвременно погибших детях); вокруг этого памятника к концу XIX — началу XX в. сформировался

(C) Белова О. В., 2019 
своеобразный народный культ, поддерживаемый также насельницами монастыря.

Подробное описание происходившего вокруг памятника (обряжение скульптур в детскую одежду, приношение денег, пряжи и кудели), а также высказывания участниц совершаемых там ритуальных практик представил в очерке «Авдотки» (1906) известный смоленский краевед, историк и знаток древностей Смоленска И. И. Орловский (1869-1909) [Орловский, 1906; 2013].

Опираясь на разновременные [Никифоров, 1853; Неверович, 1859 , 151-152; Цебриков, 1862, 279-280; Орловский, 1906; 1907, 57; Добровольский, 1914, 2-3, 938] описания паломничества, происходившего на праздник Вознесения (отметим, что, скорее всего, все они восходят к одному первоисточнику - заметке в «Смоленских губернских ведомостях» за 1853 г. [Никифоров, 1853]), мы ставим своей целью проанализировать термин авдотки с точки зрения его возможного происхождения, времени фиксации, географии и сферы употребления [см.: Добровольский, 1914, 2-3, 9; СРНГ, 1, 197; ССГ, 1, 60-61; Аникин, 1, 80-81], а также рассмотреть некоторые сюжеты городского текста, связанные с «авдотками», и показать, как традиционные поверья встраиваются в локальный текст и получают «материализацию» в связи с конкретными городскими объектами, способствуя формированию местного городского бренда.

Второй момент, на который мы обратим внимание, - это название праздника Вознесения (Ушесцье, Ушестье), которое упоминается во всех известных нам публикациях описания паломничества в Смоленск. В ряде источников оно приобретает форму Умесиье и впоследствии начинает фиксироваться словарями [Добровольский, 1914, 2 , 938; СРНГ, 47, 182; РНК, 447] в качестве самостоятельного хрононима, а именно «местного» названия праздника Вознесения. Наша задача на основе текстологического анализа источников определить причины появления этого хрононима и установить его фантомный характер.

Перспективы исследования данного сюжета мы видим в том, чтобы постараться найти новый материал, касающийся паломнической практики смоленских «авдоток» (в архивных материалах первой половины XX в. нам пока не удалось обнаружить упоминаний об этом обычае, равно как зафиксировать термин авдотки и свидетельства о паломничестве в современной устной традиции), 
уточнить, насколько распространена на Смоленщине практика приношений к «святым» местам в память умерших детей и насколько культ из Вознесенского монастыря был известен за пределами Смоленска и в самом Смоленске.

Аникин А. Е. Русский этимологический словарь. М., 2007-. Вып. 1-. Добровольский В. Н. Смоленский областной словарь. Смоленск, 1914.

Неверович $B$. О праздниках, поверьях и обычаях у крестьян белорусского племени, населяющих Смоленскую губернию // Памятная книжка Смоленской губернии на 1859 год. Смоленск, 1859. С. 123-203.

Никифоров Ф. Об особенности в г. Смоленске праздника Вознесения Господня // Смоленские губернские ведомости. 1853. № 26-27.

Орловский И. И. Авдотки. (Бытовой очерк) // Смоленская газета. 1906. № 119-120.

Орловский И. И. Краткая география Смоленской губернии. Смоленск, 1907.

[Орловский И. И.] В. С-кий. Авдотки // Смоленские мемории. Вып. 3 : А. В. Жиркевич, И. И. Орловский / сост., коммент. Ю. А. Балбышкин, М. В. Иванов, Л. Л. Степченков ; ред. К. В. Купченко. Смоленск, 2013. С. 245-258.

РНК - Атрошенко О. В., Кривощапова Ю. А., Осипова К. В. Русский народный календарь : этнолингв. словарь. М., 2015.

СРНГ - Словарь русских народных говоров / гл. ред. Ф. П. Филин (вып. 1-22) ; Ф. П. Сороколетов (вып. 23-42) ; С. А. Мызников (вып. 43-). М. ; Л. ; СПб., 1965-. Вып. 1-.

ССГ - Словарь смоленских говоров : в 11 вып. / отв. ред. Л. З. Бояринова, А. И. Иванова. Смоленск, 1974-2005.

Цебриков М. М. Смоленская губерния. СПб., 1862. (Материалы для географии и статистики России, собранные офицерами Генерального штаба ; т. 21). 